\title{
Estimation of Mercury Losses and Gold Production by Artisanal and Small-Scale Gold Mining (ASGM)
}

\author{
Akihiro Yoshimura $^{1}$ (1) $\cdot$ Koyo Suemasu ${ }^{1} \cdot$ Marcello M. Veiga $^{2}$
}

Received: 18 November 2020 / Accepted: 14 June 2021 / Published online: 7 July 2021

(c) The Author(s) 2021

\begin{abstract}
Artisanal and small-scale gold mining (ASGM) utilizes mercury ( $\mathrm{Hg})$ for the extraction of gold (Au) and is responsible for the largest anthropogenic source of emissions and releases of $\mathrm{Hg}$ to the environment. Previous estimates of $\mathrm{Hg}$ use in ASGM have varied widely. In this effort, $\mathrm{Hg}$ losses in ASGM were derived from the difference between estimates of total $\mathrm{Au}$ production and the production reported by conventional gold mining. On the basis of this result, the average ratio of $\mathrm{Hg}$ lost to Au produced in ASGM was estimated to be 1.96 in Africa, 4.63 in Latin America, and 1.23 in Asia. The difference among regions can be attributed to the amalgamation procedure used by the miners, in which whole-ore amalgamation is predominant in Latin America and Asia. The obtained estimated ratio of $\mathrm{Hg}_{\text {lost }}: \mathrm{Au}_{\text {produced }}$ suggested the possibility to detect either $\mathrm{Au}$ or $\mathrm{Hg}$ smuggling from one country to another. On the other hand, the importance of considering cyanidation in ASGM was also suggested.
\end{abstract}

The contributing editor for this article was Christina Meskers.

Akihiro Yoshimura

a.yoshimura@chiba-u.jp

1 Graduate School of Engineering, Chiba University, 1-33

Yayoi-cho, Inage-ku, Chiba-shi, Chiba 263-8522, Japan

2 Norman B. Keevil Institute of Mining Engineering,

University of British Columbia, 517-6350 Stores Road,

Vancouver, BC V6T 1Z4, Canada 


\section{Graphical Abstract}
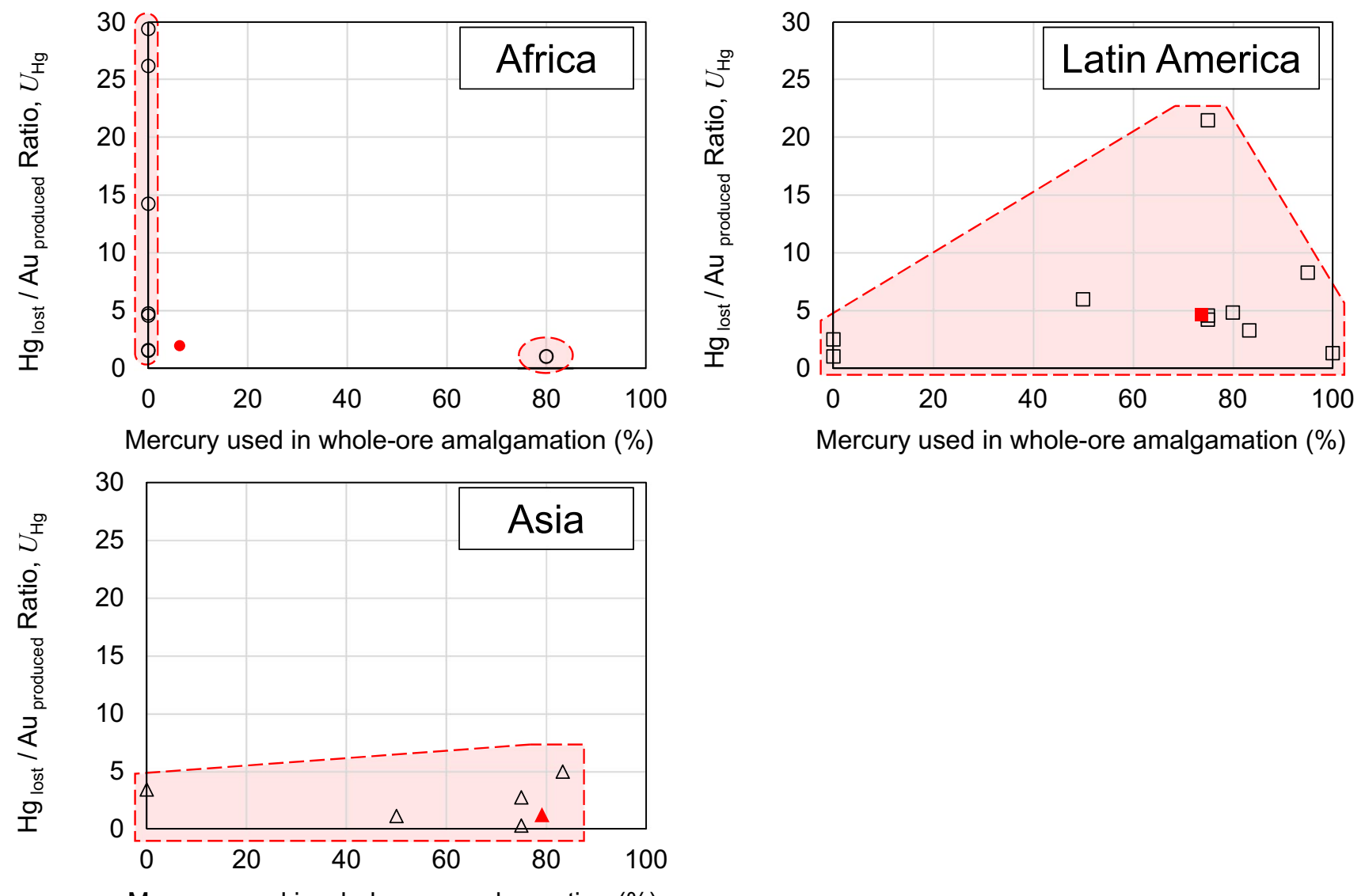

Mercury used in whole-ore amalgamation (\%)

Keywords Artisanal and small-scale gold mining $\cdot$ Mercury $\cdot$ Minamata convention $\cdot$ Substance flow analysis $\cdot$ Ore concentration

\section{Introduction}

Mercury ( $\mathrm{Hg}$ ) released [1] to the environment, including air, water, and land, causes severe environmental and health impacts. Releases from artisanal small-scale gold mining (ASGM) operations are gaining global attention due to its high contribution to the overall pollution levels. Figure 1 shows the main method of gold $(\mathrm{Au})$ extraction by ASGM [2, 3]. Gold is extracted by amalgamation of concentrates or the whole ore, and the amalgam, usually with $40-50 \%$ mercury, is heated. By heating, mercury is evaporated leaving behind the precious metals [4]. When miners amalgamate the whole ore in small ball mills, the mercury loss can be as high as 15 parts of mercury per part of gold produced [5]. It has been reported that the wholeore amalgamation process requires $10-25 \mathrm{~g}$ of mercury for the production of $1 \mathrm{~g}$ of gold while the concentrate amalgamation process requires only $1-3 \mathrm{~g}$ of mercury [6].
Amalgamation of the concentrates can definitely reduce drastically the mercury losses since less mass of material is amalgamated, usually from 0.1 to $10 \%$ of the original ore mass $[7,8]$. The selection of whole ore or amalgamation of concentrates depends on the type of ore. The whole-ore amalgamation is applied only for primary ores with relatively high grades of gold. On the other hand, as for secondary ores, which grades are usually low, miners must concentrate the gold before amalgamation $[3,4]$.

In addition, there are attempts to introduce and disseminate alternative technologies that can reduce or eliminate the use of mercury, for example, amalgamation of concentrates or cyanidation. However, most solutions are costly and complex for impoverished artisanal miners [6].

The mercury emissions, i.e., the part of the pollutant entering the atmosphere, by burning amalgams or melting gold doré at gold shops, represent the main health problem for miners and their communities as this process is usually 


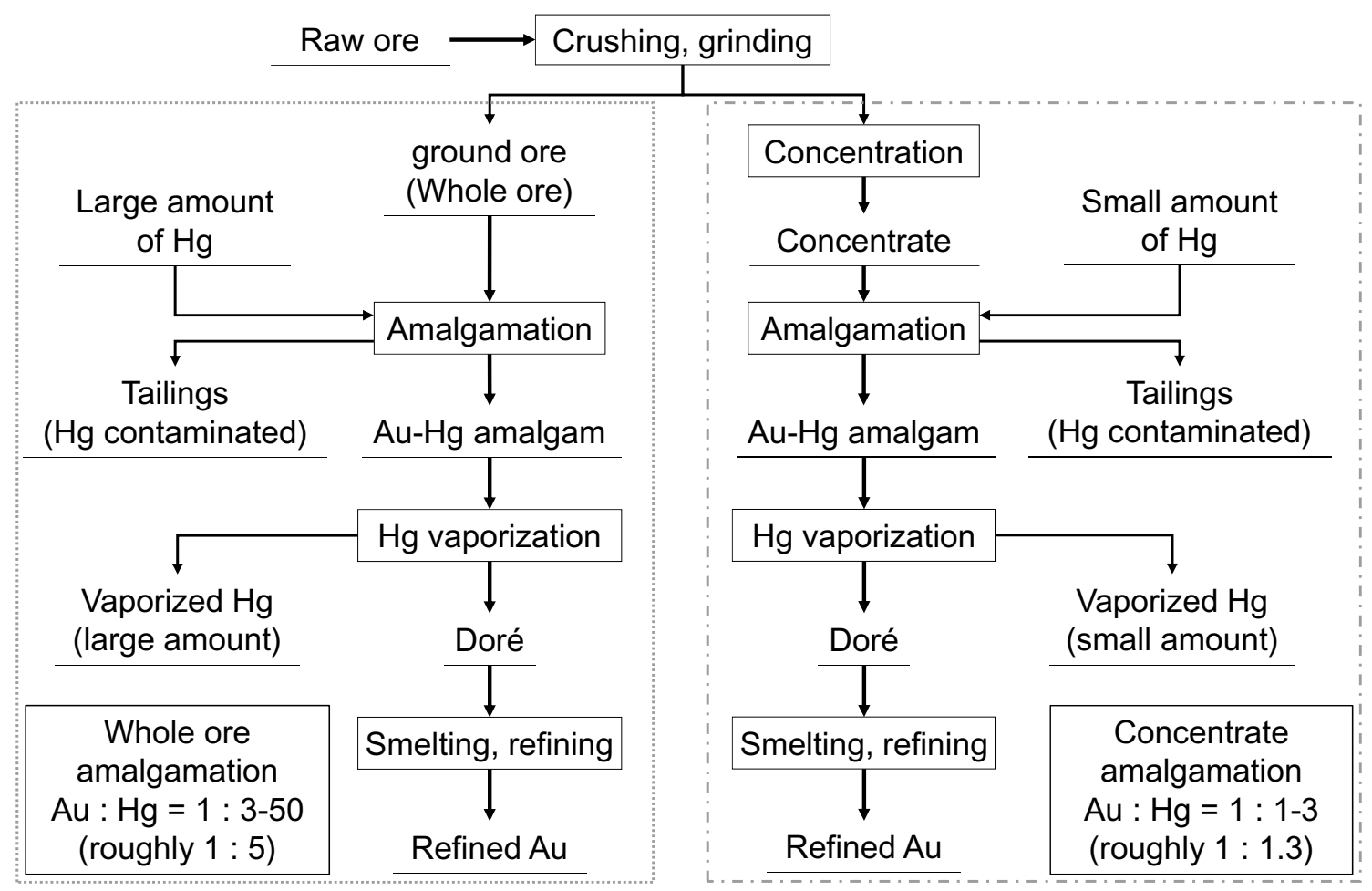

Fig. 1 ASGM processing for gold ores [2, 3]

conducted at the urban core of the artisanal mining towns [9]. The United Nations Environmental Programme [10] reported that in 2015, out of 2220 tons of mercury emitted to the atmosphere from all anthropogenic sources, ASGM represented $38 \%$. Other reports pointed out that the total mercury released to the environment including atmosphere, water, and land by ASGM can reach 2,000 tons/a [11]. The number of artisanal miners has been increasing over the years, reaching approximately 45 million individuals directly involved [12] of which at least half of this contingent is involved in gold mining, extracting as much as 450 tons/a of gold in at least 70 countries [13]. The economic crisis in developing countries caused by the Covid19 outbreak together with the recent high price of gold, around US\$2000/oz [14], definitely will contribute to substantial increase in ASGM activities worldwide.

Inaccuracies on the estimates of the levels of mercury annually released by ASGM are also caused by the uncertainties on gold production in this highly unregulated sector. Gold is constantly smuggled from one country to another to evade taxes, and this does not appear in any official statistics $[15,16]$. Even though after the UNEP Minamata Convention on Mercury that came into force in August 2017 and 128 countries signed until 2020 [17], the official imports and exports of mercury by countries also continue to be obscure. The Convention requires the country members to implement regulations to monitor the mercury trade from one country to another and to limit the mercury use in end use. This monitoring can be effective for the identification of the stakeholders in the mercury supply chain mentioned by Fritz et al. [18], which can reduce the mercury trade and supply. However, some researches pointed out that the effect of the Convention on the illegal trade is limited [19, 20]. After implementing laws prohibiting the imports and use of mercury in ASGM operations, many countries have seen a large drop in reported mercury import and use. For example, Colombia that was importing 133 tons of mercury in 2015, has officially reported only 2 tons in 2018 [21]. This actually is symptomatic for all countries legally importing mercury for legitimate use, which is later diverted to ASGM. In addition, consulting the UN COMTRADE database [21], a UN database that reports imports and exports of goods from countries, the official metallic mercury quantity imported by Peru in 2015, coming from Mexico, was approximately 12 tons. In 2018, after the country ratified the Minamata Convention in January 2016, only $34 \mathrm{~kg}$ of mercury was officially imported. With numbers of Peruvian artisanal gold miners fluctuating between 100,000 and 500,000 [22,23], it is obvious that a large part of the mercury they use is unofficially entering the country. These sudden changes in "official report" suggest the illegal and hidden flow of mercury. In addition, revealing the actual situation of the mercury and gold flow is important for achieving the purpose of the Convention. 
The gold production from ASGM and conventional gold mining (CGM) companies is not usually reported separately making it difficult to estimate the gold production from ASGM alone.

Seccatore et al. [13] estimated gold production from ASGM based on the number of miners reported by different authors and using preliminary equations elaborated by Veiga [24] in Latin America. They used the price of gold, as an "adjustment factor" for each continent. As a result, the gold production from ASGM was estimated as 85 to 90 tons in Africa, 120 to 123 tons in Asia, 194 to 255 tons in Latin America, totaling 380 to 450 tons. In order to obtain accurate estimates, each region must be analyzed separately.

In the current study, the authors estimated the ratio of mercury releases to gold produced by ASGM using the statistical information on mercury losses from AMAP-UNEP [25] and gold production from ASGM and CGM from Wood Mackenzie (WM) [26], Gold Fields Mineral Services (GFMS) [27], and United States Geological Survey (USGS) [28]. The possibility of gold smuggling to and out of the selected countries was also considered.

\section{Methods of Estimation}

\section{Gold Production}

GFMS [27] has reported the total global gold production $\left(P_{\text {Total }}\right)$ by countries in 2015 including ASGM and CGM companies. The data on gold production generated by WM [26] are only relative to the 2015 production of CGM companies. In the current study, the authors treated these data as gold production from CGM $\left(P_{\mathrm{CGM}}\right)$. Therefore, the ASGM gold production in $2015\left(P_{\mathrm{ASGM}}\right)$ was estimated by subtracting the two (Eq. 1).

$P_{\mathrm{ASGM}}=P_{\text {total }}-P_{\mathrm{CGM}}$

The current study selected countries in which ASGM is relevant, and data are supported by the authors' experience and literature. India, Nigeria, Sierra Leone, and Mozambique, where the only statistical data available for total gold production are from USGS [28], the gold production was estimated by the apportionment of "others" in the GFMS data, and applying the USGS data. The same methodology was applied to countries with both large amount of gold production and low accuracy of mercury information, such as China, Sudan, and Tanzania. In addition, the data from Ghana cited from USGS [28] have a significant difference from the gold production estimated by GFMS, but it was supported by other studies [29-31]. Another example of adaptation is the gold production from CGM companies in Zimbabwe, where the $P_{\mathrm{CGM}}$ was not recorded in the data of WM [26]; however, Ndamba et al. [32] reported that approximately $42 \%$ of gold production was from ASGM. In Asia, Cambodia was excluded from our study because of the lack of gold production data and Laos because of its CGM production in 2015 exceeding the total production as reported by WM [26].

\section{Mercury Losses}

The UNEP Global Mercury Assessment estimated the amount of mercury released by artisanal miners to land and water [25] to be $59.3 \%$ of the total mercury lost, and the remaining $40.7 \%$ was emitted to the atmosphere. This organization estimated that ASGM in 81 countries lost to the environment in 2017 an average of 2058.9 tons/a of mercury with amounts ranging from 985.9 to 3131.9 tons/a. An error of the total mercury loss from ASGM was $\pm 74 \%$. The AMAP-UNEP [25] estimates also considered the percentage of mercury that was used in the amalgamation of the whole ore in selected countries.

This work estimated the mercury lost per unit of gold produced as $U_{\mathrm{Hg}}$ calculated by Eq. (2). In this formula, $\mathrm{Hg}_{\text {lost }}$ is the quantity cited by AMAP-UNEP [25] and $\mathrm{Au}_{\text {produced }}$ is the estimated gold production from $\operatorname{ASGM}\left(P_{\mathrm{ASGM}}\right)$.

$U_{\mathrm{Hg}}=\frac{\mathrm{Hg}_{\text {lost }}}{\mathrm{Au}_{\text {produced }}}$

This ratio was then compared with the proportion of whole-ore amalgamation in the selected countries suggested by AMAP-UNEP [25]. As mentioned above, the whole-ore amalgamation would cause larger $U_{\mathrm{Hg}}$ than the amalgamation of concentrates. If there are inconsistencies between the $U_{\mathrm{Hg}}$ and the proportion of whole-ore amalgamation, the discrepancy can be attributed to mercury or gold smuggled from one country to another, for example.

Table 1 shows the targeted countries, mercury loss in ASGM, and total gold production with their sources [25, 27, 28]. In the current study, the authors focused on the countries with a high reliability of the information on mercury loss to calculate the $U_{\mathrm{Hg}}$.

\section{Results and Discussion}

\section{Global Trend}

Table 1 shows the total gold production and the proportion coming from ASGM in the selected countries. Figure 2 shows $U_{\mathrm{Hg}}$ in ASGM and the percentage of mercury being used in whole-ore amalgamation, according to assessment from AMAP-UNEP [25]. 
Table 1 Target countries, their Au production data, and estimated results in the current study

\begin{tabular}{|c|c|c|c|c|}
\hline Country & $\begin{array}{l}\mathrm{Hg} \text { loss in ASGM process, } L_{\mathrm{Hg}} / \\
\text { tons year }{ }^{-1}[25]\end{array}$ & $\begin{array}{l}\text { Total Au production, } P_{\text {total }} / \\
\text { tons year }\end{array}$ & $\begin{array}{l}\text { ASGM proportion }(\%) \\
\text { [26-28] }\end{array}$ & $\mathrm{Hg}$ loss unit, $U_{\mathrm{Hg}}(\mathrm{t} / \mathrm{t})$ \\
\hline \multicolumn{5}{|l|}{ Africa } \\
\hline Burkina Faso & 35.1 & 38.0 [27] & Less than 10 & $10-20 *$ \\
\hline Ghana & 70 & $125.3[28]$ & $25-50$ & $1-3$ \\
\hline Guinea & 19.1 & $20.0[27]$ & $10-25$ & $3-5^{*}$ \\
\hline Mali & 12.5 & $49.0[27]$ & $10-25$ & $1-3$ \\
\hline Mozambique & 4 & $1.52 \times 10^{-1}[27,28]$ & 100 & $20-30 *$ \\
\hline Nigeria & 20 & $3.15 \times 10^{-3}[27,28]$ & 100 & Over $1000 *$ \\
\hline Senegal & 3 & $5.8[27]$ & Less than 10 & $20-30 *$ \\
\hline Sierra Leone & 11 & $6.75 \times 10^{-2}[27,28]$ & 100 & $100-200^{*}$ \\
\hline Sudan & 83 & $82.4[28]$ & $90-100$ & $1-3$ \\
\hline Tanzania & 35 & $46.8[27]$ & $10-25$ & $3-5^{*}$ \\
\hline Zimbabwe & 25 & $22.0[27]$ & 042 & $1-3$ \\
\hline \multicolumn{5}{|l|}{ Latin America } \\
\hline Bolivia & 120 & $12.2[27]$ & $90-100$ & $20-30 *$ \\
\hline Brazil & 105 & 84.8 [27] & $10-25$ & $5-10^{*}$ \\
\hline Colombia & 175 & $53.2[27]$ & $90-100$ & $3-5$ \\
\hline Ecuador & 85 & $17.6[27]$ & 100 & $3-5$ \\
\hline French Guiana & 7.5 & $3.0[27]$ & 100 & $1-3$ \\
\hline Guyana & 15 & $15.7[27]$ & $90-100$ & $1-3$ \\
\hline Honduras & 5 & $2.6[27]$ & Less than 10 & Over $1000 *$ \\
\hline Nicaragua & 3.5 & $8.0[27]$ & $25-50$ & $1-3$ \\
\hline Peru & 327 & $177.9[27]$ & $25-50$ & $3-5$ \\
\hline Suriname & 63 & 23.9 [27] & $50-75$ & $3-5^{*}$ \\
\hline Venezuela & 102 & 24.2 [27] & 100 & $3-5$ \\
\hline \multicolumn{5}{|l|}{ Asia } \\
\hline China & 100 & $454.1[27]$ & $50-75$ & Less than 1 \\
\hline India & 6 & $1.8[27,28]$ & 100 & $3-5$ \\
\hline Indonesia & 420 & $176.3[27]$ & $25-50$ & $3-5$ \\
\hline Mongolia & 11.5 & 31.3 [27] & $25-50$ & $1-3$ \\
\hline Philippines & 70 & 46.7 [27] & $50-75$ & $1-3$ \\
\hline
\end{tabular}

The calculated ratio with * indicates possible exaggeration on $\mathrm{Hg}$ loss or underestimation of gold production

Causes can be gold smuggling, gold production from artisanal by cyanidation, or even errors on the original estimates of $\mathrm{Hg}$ and $\mathrm{Au}$

In most African countries, the proportion of gold production by ASGM represents 10 to $20 \%$ of the total gold production of the countries, as CGM companies have a larger importance. The exception is those countries with exclusive (100\%) gold production from artisanal gold operations but with small amount, like Mozambique, Nigeria, and Sierra Leone. In contrast, except for Brazil and Peru, the participation of ASGM in gold production in Latin America is high in most countries. In Asia, this proportion ranged from 25 to $75 \%$, except in India as its reported gold production is 2 tons/a from a CGM company and no significant ASGM is reported.

The $\mathrm{Hg}_{\text {lost }} / \mathrm{Au}_{\text {produced }}$ ratio, $U_{\mathrm{Hg}}$ was estimated lying between 1 and 5 in most countries, with a global average of 2.6. However, this ratio was above 10 in some countries, where whole-ore amalgamation in ball mills is predominant [5].

\section{Africa}

As well observed by AMAP-UNEP [25], there is no evidence that African countries are extensively using whole-ore amalgamation in ball mills. Some countries, like Zimbabwe, use whole-ore amalgamation on copper-amalgamating plates but the mercury losses are at least 5 times less than when the ore is ground with mercury [33]. In the cases of Nigeria and Sierra Leone, the high $U_{\mathrm{Hg}}$ ratios were caused by the discrepancy between the reported gold production and the large mercury use and lost in these countries. The total gold productions in 2015 in these countries were estimated 
Fig. 2 Percentage of mercury used in whole-ore amalgamation and the estimation of ratio $\mathrm{Hg}_{\text {lost }} / \mathrm{Au}_{\text {produced }}$

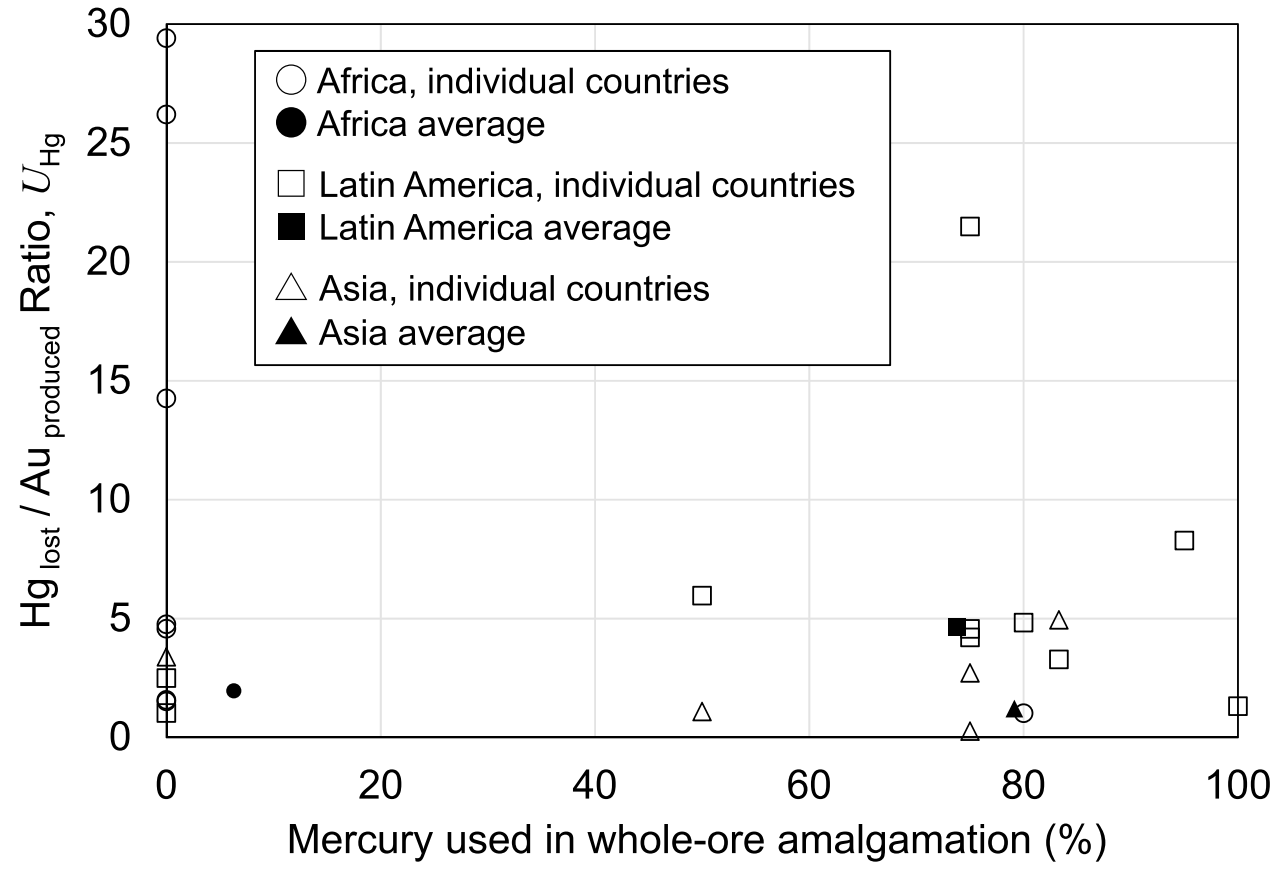

as 0.0675 tons/a and $3 \mathrm{~kg} / \mathrm{a}$ for Sierra Leone and Nigeria, respectively [27, 28], while the use of mercury was reported as 5.5 tons/a and 10 tons/a, respectively [25]. However, the gold production in Nigeria was reported as 4 to 8 tons in the other publications [34, 35] and even 13.7 tons/a (97 tons between 2012 and 2018) in a press article [36]. The $U_{\mathrm{Hg}}$ ratios of both countries would be approximately 1 considering that these reports and results match the ratio typically related to amalgamation of concentrates [3, 4]. In general, these high ratios were likely caused by either the underestimation of gold production in these countries or overestimates of mercury losses. In most cases, the underestimation of gold production is the main reason of the high $U_{\mathrm{Hg}}$.

In 2006 and 2008, it was observed in the field in Manica, Mozambique that artisanal miners were using manual-driven ball mills made of gas tanks, which was followed by gold concentration by panning $[37,38]$. At that time, miners were amalgamating only the concentrates, but, despite the low loss of mercury, of on average 4 tons/a, our data suggest that whole-ore amalgamation is currently occurring in the country. The calculated $U_{\mathrm{Hg}}$ ratio for Mozambique is high if we consider the total production of 0.242 tons/a of gold in 2015 exclusively from ASGM. However, the USGS [28] indicated that Mozambique produced exclusively by ASGM approximately 2.6 tons/a and 2.4 tons/a of gold in 2016 and 2017, respectively. It is assumed that the gold production information of this country is uncertain, and more gold than officially reported was actually produced in 2015.

All artisanal miners in Africa, except the Zimbabwean miners produce their gold exclusively from amalgamation of gravity concentrates. One reason for this less polluting method is the fact that each individual miner uses very primitive manual method and mercury is an expensive item in the process. The whole-ore amalgamation proportion indicated by AMAP-UNEP [25] in Zimbabwe was $80 \%$, which seems correct as most processing centers use copper-amalgamating plates after the grinding process [7, 39]. However, Zimbabwean miners extract gold using a combined amalgamation and cyanidation process [7]. This means that the portion of the produced gold from ASGM (using mercury) will be overestimated, and $U_{\mathrm{Hg}}$ will be underestimated in our methodology.

The lack of accountability together with gold smuggling makes it hard to obtain reliable figures about gold production by ASGM in some countries. This is supported by a previous study by UNEP [10]. This causes a systematic increase in the $U_{\mathrm{Hg}}$ ratio. For example, the mercury losses in Sierra Leone are on average 11 tons $\mathrm{Hg} / \mathrm{a}$ [25], whereas the gold production reported by USGS [28] was 0.107 tons in 2016. As the gold in the country comes entirely from ASGM, this generates a very high $U_{\mathrm{Hg}}$ ratio. One of the important factors for this is that likely gold has been smuggled from Sierra Leone to neighboring countries as observed by other studies [35, 40]. Assuming that gold has been smuggled, the mercury loss is accounted for Sierra Leone without producing gold, while the gold produced is accounted for the neighboring countries without mercury lost. This inconsistency causes a very high $U_{\mathrm{Hg}}$.

Gold smuggling from Zimbabwe [41] also makes it difficult to quantify the actual production levels in this country. It is interesting to notice that the estimates of $U_{\mathrm{Hg}}$ suggest the possibility of detecting smuggling operations. 
The $U_{\mathrm{Hg}}$ of Burkina Faso was between 10 and 20, and that of Guinea was between 3 and 5. These seem high values, considering that, as observed in the field, most gold has been produced from gravity concentration processes. This might be caused by the wrong estimates of mercury lost or gold produced caused by smuggling. For example, the gold smuggled from Burkina Faso to Togo was estimated in 2017 as over 7 tons/a [42] while $P_{\mathrm{ASGM}}$ was reported as less than 3 in 2015. This means that the undetected $P_{\mathrm{ASGM}}$ may be larger than the official reported gold production. In addition, Burkina Faso is reported to be responsible for much of the illegal mercury trade in the region [35]. This uncertainty causes the exaggerated $U_{\mathrm{Hg}}$ of Burkina Faso.

In the current study, the production of gold from ASGM in Mali was considered as less than 3 tons/a. The obtained $U_{\mathrm{Hg}}$ for Mali was between 1 and 3 which is similar to previous studies [3, 43] despite the lack of reliable data [42]. This estimate reflects the results of government enforcement against informal mining operations [44].

Moreover, gold smuggling in the West Africa region including Burkina Faso, Cote d'Ivoire, Guinea, and Mali is highlighted [42]. The governments of these countries charge a 3\% export tax. However, in Mali, this applies only to the first $50 \mathrm{~kg}$ while other governments apply this to all exported gold. This tax difference suggests that Mali is the "loophole" or the "biggest conduit" of the gold smuggling in this region [42]. This also suggests the requirement of more reliable investigation of the smuggling activities in this region for the accurate quantification of gold production from ASGM and $U_{\mathrm{Hg}}$. Ghana's $U_{\mathrm{Hg}}$ was calculated to be between 1 and 3 . Several scholars reported that most gold has been produced from amalgamation of concentrates in this country [25, 45]. For example, $210 \mathrm{~g}$ of mercury was added to a concentrate (and not all was lost) and around $200 \mathrm{~g}$ of gold was obtained [46]. ASGM in Ghana is often operated by informal miners called as "galamsey" [47]; however, both legal and informal operators use similar methods [46]. Our calculation results matched previous studies $[3,43]$. The authors had information from Ghanaian experts about the operation of hundreds of small processing centers in Ghana using amalgamation and cyanidation that, as a result, reduces the estimated $U_{\mathrm{Hg}}$. This was also mentioned by Armah et al. [48]. Therefore, the $U_{\mathrm{Hg}}$ of $1-3$ seems appropriate for this country with more than 1 million artisanal miners [47, 49].

The $U_{\mathrm{Hg}}$ of Senegal was estimated between 20 and 30 which is extremely high, as this ratio was estimated as 1.37 in 2018 by the Artisanal Gold Council (AGC) [50]. This difference is caused by the underestimation of gold production by Senegalese ASGM. Most gold produced in the country is from CGM and a good part of gold produced by ASGM might be smuggled to Mali as pointed out by Alvarez et al. [51].

Tanzania's $U_{\mathrm{Hg}}$ of 5 , where miners amalgamate only the concentrates, seems to be relatively high considering that the amalgamation of concentrates generates a $U_{\mathrm{Hg}}$ around $1-3$ as described above [3, 4]. This can be caused by the large-scale gold smuggling as mentioned by Blore [52]; for example, in 2010, the gold export from Tanzania to Kenya was only 1.3 tons while smuggling to Dubai was 13.5 tons.

Figure 3 shows $U_{\mathrm{Hg}}$ in ASGM and the \% of the mercury being used in whole-ore amalgamation of Africa, extracted from Fig. 2. The average percentage of the mercury used in
Fig. 3 Percentage of mercury used in whole-ore amalgamation and the estimation of ratio $\mathrm{Hg}$ lost $/ \mathrm{Au}$ produced of Africa

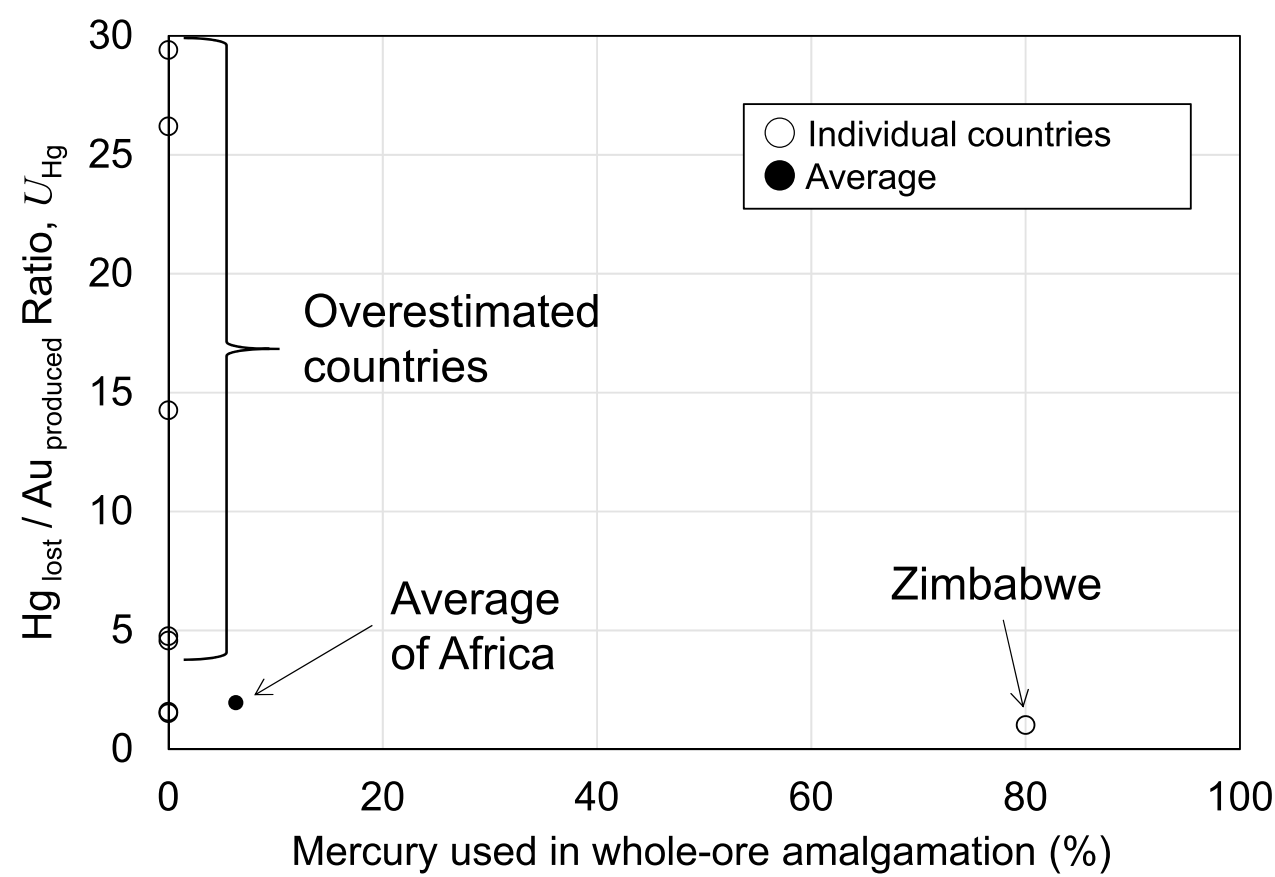


whole-ore amalgamation and $U_{\mathrm{Hg}}$ for the targeted countries in Africa was $6.3 \%$ and 1.96, respectively. These results are similar to the ones from previous studies [3, 43].

\section{Latin America}

According to AMAP-UNEP [25], the percentage of the mercury that is used for whole-ore amalgamation in Latin American countries is over 50\%, and in some cases, like in Nicaragua, $100 \%$. However, the average $U_{\mathrm{Hg}}$ was estimated between 1 and 3, and this seems to be underestimated considering the high predominance of whole-ore amalgamation. In fact in Nicaragua, like in other Central American countries, the use of the whole-ore amalgamation in the rudimentary grinding "rastras" is the predominant method and main cause for mercury losses to the tailings [7, 53]. Mercury is added to the "rastras" which are blocks of stones rotating over a cement floor, and copper plates capture part of the mercury that comes out in the overflow of the pulp. In this process, the $U_{\mathrm{Hg}}$ usually becomes higher than 6 [54]. Nevertheless, a large number of miners also extracts gold from alluvial ores with dredges where they use no or very little mercury to amalgamate the concentrates [56]. Therefore, the average $U_{\mathrm{Hg}}$ between 1 and 3 seems adequate to reflect the country's average.

On the other hand, $U_{\mathrm{Hg}}$ of Honduras was estimated as over 1,000, and, even with the intense use of "rastras" for whole-ore amalgamation, this huge ratio was caused by the underestimation of gold production from ASGM or smuggling. In Honduras, the number of workers in ASGM has increased rapidly since the early 2000s [57], whereas the reported total gold production has been decreasing [27] in particular due to the closure of the Vueltas del Rio Mine operation from the CGM company Rio Narcea in 2004 [58]. This contradiction suggests the unreported production of gold.

In South America, $U_{\mathrm{Hg}}$ was extremely large in Bolivia and relatively large in Brazil and Suriname while much lower in Guyana. The $U_{\mathrm{Hg}}$ in Bolivia was between 20 and 30, and this was caused by three factors: (1) the tendency of adding mercury in small ball mills, (2) the underestimation of the gold production due to the inaccurate information or smuggling $[59,60]$, and (3) Bolivia has been exporting the imported mercury to neighboring countries [61]. The calculated $U_{\mathrm{Hg}}$ in Brazil was between 5 and 10 which seems exaggerated as, despite the evidence of the use of copper-amalgamating plates, most artisanal miners, in particular in the Amazon region, work with low-grade alluvial or colluvial ores, where only concentrates are amalgamated [62]. It was observed in the field that many miners do not sell gold through official channels and transform it into jewels. This can be a reason for this high $U_{\mathrm{Hg}}$. Another reason is that, since 1989, mercury cannot be used in ASGM without a government certificate [63]; therefore, most mercury enters Brazil clandestinely, likely from Guyana [64]. The only official data of metallic mercury imports to Brazil revealed 20.1 tons in 2019 coming from Japan, whereas nothing was imported in 2015 [21]. On the other hand, gold productions from ASGM in 2015 and 2019 in Brazil were very similar [27].

The amalgamation of the whole ore in ball mills by artisanal miners is the dominant process in Bolivia, Colombia, Ecuador, and Peru, in which the $U_{\mathrm{Hg}}$ can be as high as 15 [5]. Except in Bolivia, where miners have their own processing plants, gold ores are extracted in processing centers that provide, for a nominal fee, the amalgamation of the wholeore extracting, on average, less than $30 \%$ of the gold. Then the centers use cyanidation to extract the residual $70-80 \%$ gold from tailings [7]. The gold produced by cyanidation in these rudimentary processing centers contributes to reducing the $U_{\mathrm{Hg}}$ resulting in a ratio between 3 and 5. On the other hand, the reported $U_{\mathrm{Hg}}$ in previous studies was 2.10 in 2013 in Ecuador [65] and 2.8 in 2007 in Peru [66], respectively. These results were relatively lower than our estimation. However, these studies targeted specific gold production sites where a large number of miners amalgamate only concentrates and also cyanidation is a common practice to extract gold from tailings [7].

The illegal flow of mercury in the Guianas, consisting of Guyana, Suriname, and French Guiana, is well known and it has been a long-term problem. Only Guyana can import mercury legally while Suriname has established more restrictive rules, and French Guiana has prohibited mercury imports [67]. In addition, the imported amount of mercury into Guyana was larger than the amount used by ASGM. At last, there is no official export of mercury from Guyana after 2003 [67]. According to UN COMTRADE [21], Suriname and French Guiana did not report any import or re-export of mercury in the last 5 years. Meanwhile, Guyana has imported, 29 tons of metallic mercury in 2015, 35 tons in 2016, 10.5 tons in 2017, and approximately 22 tons in 2018. However, the AMAP-UNEP [25] reported the average use of 63 and 7.5 tons of mercury in Suriname and Guyana, respectively. It is very possible that some of the mercury imported by Guyana has been sold in the neighboring countries, but other sources of mercury would be needed to match the Surinamese data from AMAP-UNEP [25]. Veiga and Marshall [68] indicated that Cuba has been importing high amounts of mercury from Canada since 2011; for example, according to UN COMTRADE [21], in 2016, 2017, and 2018, Canada exported or re-exported 76,125 , and 91 tons of mercury to Cuba, respectively. It is not clear what the use of mercury is in Cuba as there is no information about exports of mercury from this country. Also in the case of Suriname, 63 tons of mercury use and lost [25] seems to be inaccurate, as most Surinamese miners extract gold from wet and dry alluvial deposits as well as from colluvial deposits. The gold grades 
in these ores are very low, and therefore, miners need to concentrate the gold before amalgamation [69-71]. Our calculated $U_{\mathrm{Hg}}$ of 3 and 5 for Suriname seems too high for the types of ores mined and processed in the country.

In Venezuela, in spite of the gold production by cyanidation from a state-owned company [72], the proportion of gold produced by ASGM was considered herein as $100 \%$ as a result of our calculation. The reported production of this company, CVG Minerven, has decreased from 4.2 tons/a in 2009 to 0.43 tons/a in 2015 according to Siverio [72] or, according to Wagner [73], from 2.0 tons/a in 2012 to 0.87 tons/a in 2014. In addition, CGM gold production by Venezuela was recorded until 2013 by WM [26] and declined to zero after 2014. This drastic decrease of gold production from the official sector seems to be the cause of the lack of information by WM [26].

Figure 4 shows $U_{\mathrm{Hg}}$ in ASGM and the percentage of the mercury being used in whole-ore amalgamation in Latin America, extracted from Fig. 2. The average percentage of the mercury used in whole-ore amalgamation ratio and $U_{\mathrm{Hg}}$ for the targeted countries in Latin America was $73.8 \%$ and $4.63 \mathrm{t} / \mathrm{t}$, respectively. These results are similar to those from previous studies $[3,43]$.

\section{Asia}

Indonesia is one of the most active countries in terms of ASGM operation. It has been estimated that 1 million artisanal gold miners are active in 27 provinces out of the 34 provinces in the country $[74,75]$. A report has indicated that 380 tons of mercury are released and emitted annually to the environment [76]. From the production of artisanal mercury mines [77], the country changed from importing 10 tons of mercury in 2009 to exporting nearly 700 tons in 2016 [21]. Indonesian artisanal miners are losing 213.5 tons/a of mercury to the environment as $83.3 \%$ of the mercury is used in the whole-ore amalgamation process [25], usually in small ball mills ("tromols") [78]. Veiga et al. [7] mentioned that the gold production in Indonesia is not clearly publicized but the government believes that it must be between 60 and 80 tons/a. We have estimated that the Indonesian gold production by ASGM was approximately 80 tons in 2015 . The average calculated $U_{\mathrm{Hg}}$ was between 3 and 5 which reflects a mix of whole-ore amalgamation, amalgamation of concentrates in alluvial deposits in Kalimantan and cyanidation [7, 77].

The AMAP-UNEP [25] estimates for the Philippines were that ASGM loses in average 35 tons/a of mercury of which $75 \%$ in whole-ore amalgamation. Using our methodology, the calculated gold production from ASGM was approximately 25 tons in 2015 , and the calculated $U_{\mathrm{Hg}}$ was near to 3 . This result may be underestimated considering that the whole-ore amalgamation was the predominant procedure in Philippines [7, 79]. The extraction of gold by cyanidation from tailing in Philippines is also reported [6]. This means that part of gold from ASGM was produced without mercury, and the $U_{\mathrm{Hg}}$ would be underestimated in our methodology. In addition, with as many as 500,000 artisanal gold miners, and producing approximately 37 tons of gold in 2018 [80], the actual production may be higher, due to gold smuggling that can affect up to $90 \%$ of the ASGM production [81]. In fact, the government of Philippines recognizes the smuggling problem as the purchasing of gold
Fig. 4 Percentage of mercury used in whole-ore amalgamation and the estimation of ratio $\mathrm{Hg}_{\text {lost }} / \mathrm{Au}$ produced of Latin America

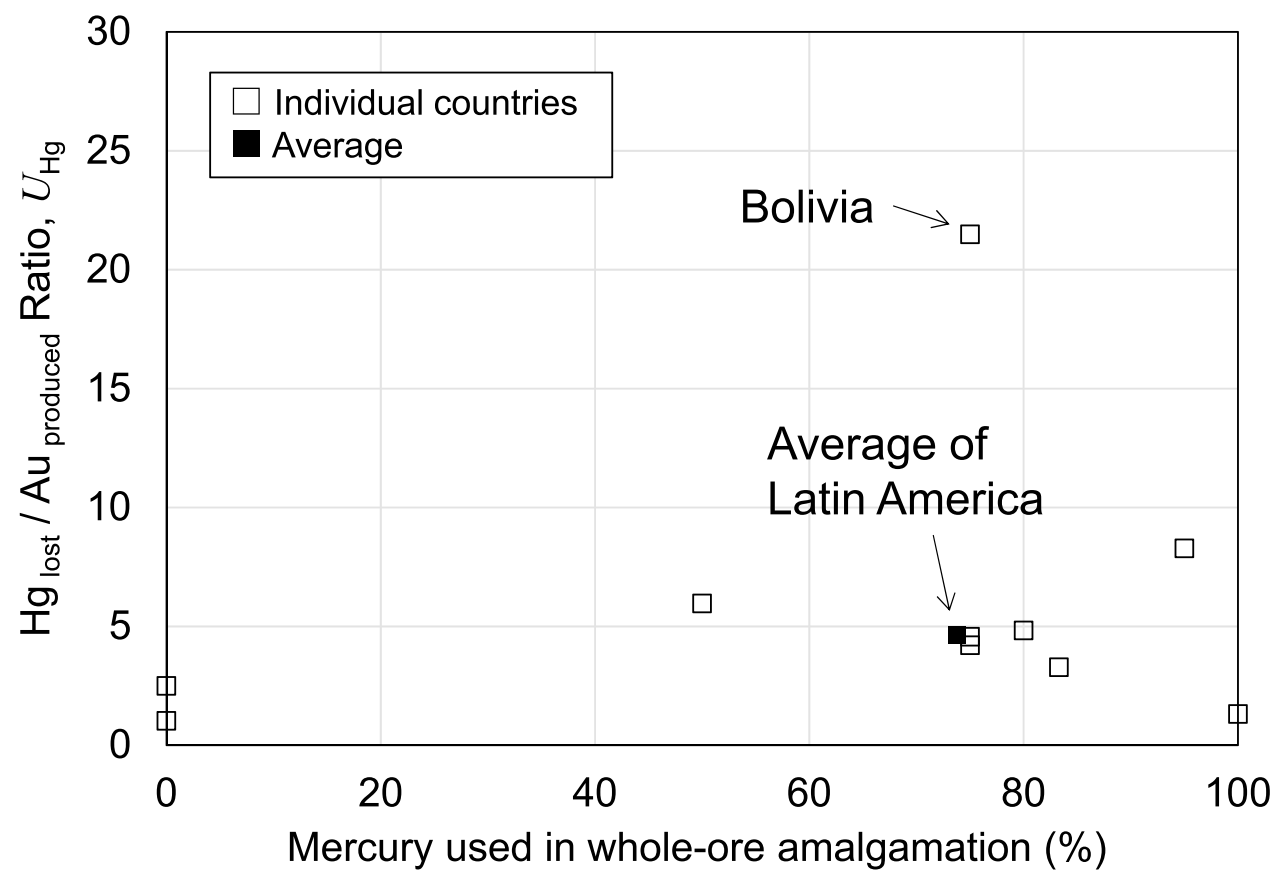


by the Central Bank, the only official gold buyer, in 2010, was approximately 28 tons and declined to 0.31 tons in 2019 [82]. These factors caused the underestimation of Philippines's $U_{\mathrm{Hg}}$.

In Mongolia, the AMAP-UNEP [25] estimated 11.5 tons of mercury on average lost by ASGM in the country, of which $50 \%$ is due to the whole-ore amalgamation. According to Singo and Seguin [83], the ASGM sector contributed in 2017 with more than $50 \%$ of the country's gold production, involving over 60,000 miners. In our calculation, $U_{\mathrm{Hg}}$ might be approximately or even lower than 2 . This result suggests the prevailing amalgamation of concentrates at the end stage of the gravity concentration.

The AMAP-UNEP [25] report considered that 3 tons/a of mercury was lost to the environment by ASGM in India. Deb et al. [84] described a number of sites where artisanal miners extract gold from placer and primary rocks in India. Deb [85] estimated that $60-80 \mathrm{~kg}$ of gold is produced annually by this sector releasing 6 to 8 tons of mercury. This seems exaggerated but, in fact, despite the detailed description of the sites mined by artisanal gold miners [86], very little information is available in the literature about how these miners use mercury in India. The predominant idea is that mercury is used to amalgamate concentrates; however, our calculation derived a $U_{\mathrm{Hg}}$ of 3 and 5 indicating that mercury is also used to amalgamate the whole ore, disagreeing with the AMAP-UNEP [25] estimate that mercury is exclusively used in gravity concentrates. This estimate must be carefully used due to the lack of information about ASGM activities in the country.

The main gold mine in Laos, Sepon Mine owned by China's Chifeng Jilong Gold Mining, intends to produce from 1 to 1.6 tons of gold in 2020 and 7 tons in 2021 [87]. The USGS [28] reports approximately 6 tons of gold produced in the country in 2017. Laos is a promising country for CGM companies, with 35 known primary gold deposits and 115 placer gold sites, which is translated into a total of 100 gold mining permits granted in 2017 [88]. These authors mentioned that, despite the presence of 1000 artisanal miners extracting placer gold, these informal activities were considered illegal in 2006 and little information is available. However, Moretti and Garrett [89] estimated between 15,000 and 50,000 full-time artisanal miners in the country. The main gold placer operations occur in the Mekong River and the Nam Ou River in Luang Prabang Province. Baker et al. [90] reported that 8,000 miners are active in the Bokeo and Luang Prabang provinces but with possibility of reaching 15,000 miners. These authors reported that the $U_{\mathrm{Hg}}$ ratio in alluvial operations was approximately 1 to 2 as only gravity concentrates, obtained by panning or sluicing, were amalgamated. However, when primary ores were processed in hammer mills and copper-amalgamating plates, this ratio was approximately 3 . Most information about gold production in Laos is 15-20 years old and reports a gold production of much less than $10 \mathrm{~kg}$ gold per year. In spite of the estimates of AMAP-UNEP [25] of an average of 1.5 tons of mercury being lost annually in the Laotian ASGM operations, we adopted the $U_{\mathrm{Hg}}$ ratio of 2 .

China is another country with little information about the gold production by ASGM. Gunson and Veiga [91] estimated that approximately 6.5 million artisanal miners extract many different minerals of which coal, iron ore, and gold are the main ones. These authors cited that the $U_{\mathrm{Hg}}$ ratio in ASGM operations is very variable from 1 , for alluvial operations, to 14 for grinding ore with mercury but very likely averages approximately 3 , as most observed operations were using whole-ore amalgamation in Chilean mills followed by copper-amalgamating plates. However, China's $U_{\mathrm{Hg}}$, estimated by our procedure, was less than 1 . The AMAP-UNEP [25] estimated that ASGM loses in average 100 tons of $\mathrm{Hg}$ of which $25 \%$ of the operations are whole-ore amalgamation. China officially banned ASGM in 1990s; however, ASGM has been continued because of its large economic profits. The lack of official numbers and documents about artisanal gold mining in China makes it difficult to obtain reliable estimates about the gold production and mercury losses.

Figure 5 shows $U_{\mathrm{Hg}}$ in the Asian ASGM sector and the percentage of the mercury lost when the whole-ore amalgamation is used. The average percentage of the mercury used in whole-ore amalgamation and $U_{\mathrm{Hg}}$ for the targeted countries in Asia were approximately $79 \%$ and 1.23 , respectively. These results do not fit the tendency of previous researches $[3,43]$. These inconsistencies were caused by the uncertainness in the data from China gold production and the mercury losses.

\section{Conclusion}

In the current study, the authors estimated a ratio $\mathrm{Hg}_{\text {lost }} /$ $\mathrm{Au}_{\text {produced }}\left(U_{\mathrm{Hg}}\right)$ in the ASGM operations of selected countries. As a result, the $U_{\mathrm{Hg}}$ for the African countries, where most artisanal gold is produced from amalgamation of gravity concentrates was approximately 1 to 2 , whereas in Latin America and Asia, where whole-ore amalgamation combined with cyanidation of the tailings is the predominant process, the $U_{\mathrm{Hg}}$ was between 4 and 5. The whole-ore amalgamation, in particular in small ball mills, loses larger proportions of the mercury initially introduced in the process than amalgamation of gravity concentrates. Whole ore amalgamation, in particular in ball mills, derives a $U_{\mathrm{Hg}}$ usually above 10, but with adjustments of the process, for example reducing the mill speed, this can be reduced to 6 , which is still high [54]. This high ratio occurs due to the pulverization and oxidation of the mercury drops in the grinding process. 
Fig. 5 Percentage of mercury used in whole-ore amalgamation and the estimation of ratio $\mathrm{Hg}_{\text {lost }} / \mathrm{Au}$ produced of Asia

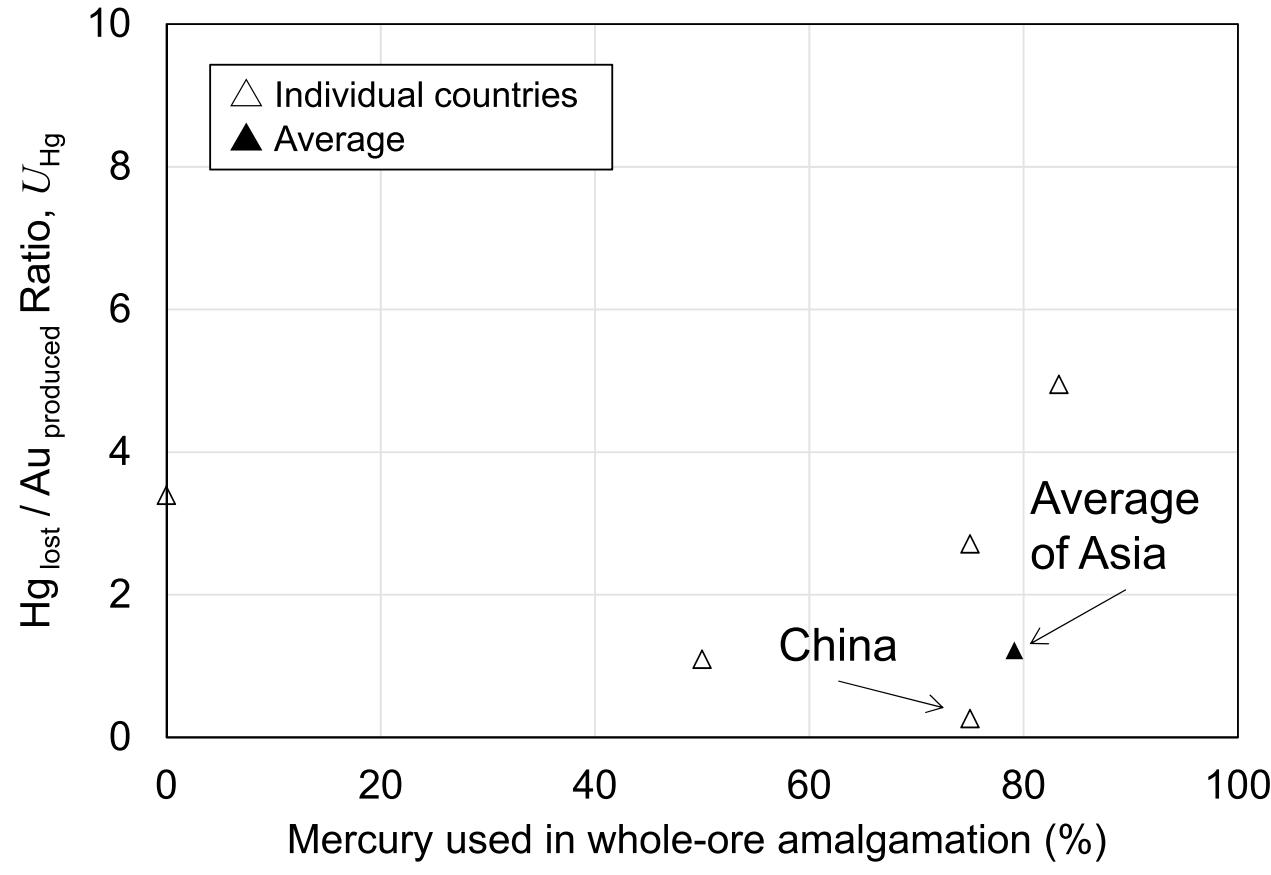

Mercury loses coalescence and does not amalgamate the gold. This study confirms this trend.

The very high estimated $U_{\mathrm{Hg}}$ for some countries was caused by the underestimation of gold production or the overestimation of mercury loss. In the countries with high estimated $U_{\mathrm{Hg}}$, the smuggling of mercury or gold has been highlighted in various studies which justifies our results. This suggests that this methodology has a possibility to detect unregulated flows of mercury and gold.

As described in the Introduction, the Minamata Convention on Mercury often caused the unregulated flow of mercury, although it targets the mercury trade monitoring and the use limitation in end use. This flow was caused by the illegality of mercury supply and use in ASGM activities, e.g., the management by illegal groups in Burkina Faso [35]. Moreover, not only criminal organizers but also corrupt governments are involved in the illicit ASGM activities [92]. Such situation can create a regional network of mercury trade, sometimes mentioned as a "pipeline" as observed in the Amazon region [93]. It has been very difficult to obtain accurate information about mercury sales, as most developing countries have adhered to the Minamata Convention and they prefer to officially report to UN COMTRADE that no more mercury is officially entering the countries. From now on, most data on mercury losses and gold production must rely on field research projects, local informers, and investigating reporters, since official numbers from governments are not reflecting the reality $[94,95]$.

Our procedure which evaluated individual results with regional averages from previous studies, enabled us to detect unregulated flows of mercury and gold, although the assessment of $U_{\mathrm{Hg}}$ was limited to the countries with consistent information in the current study. This enables the Minamata Convention signatory countries to prioritize actions to curb mercury smuggling as well as illicit gold trades.

The increasing production of gold by artisanal cyanidation of amalgamation tailings, as observed in Bolivia, Colombia, Ecuador, Ghana, Indonesia, Peru, Philippines, Zimbabwe, and other countries, decreases the $U_{\mathrm{Hg}}$ giving the impression that mercury losses are being reduced. This is nowadays a major pollution concern as $\mathrm{Hg}$-cyanide complexes are toxic to aquatic life [96]. The current study calls attention that future studies of mercury and gold production by ASGM should consider the cyanidation of $\mathrm{Hg}$ contaminated tailings.

Acknowledgements This research was performed with the support of the Environment Research and Technology Development Fund (JPMEERF20195R52) of the Environmental Restoration and Conservation Agency of Japan. The open access publishing was financially supported by Taiheiyo Cement Corporation. In addition, Prof. Yasunari Matsuno, from Chiba University, Prof. Kazuki Morita and Prof. Takeo Hoshino, from the University of Tokyo, Assoc. Prof. Takashi Nagai, from Chiba Institute of Technology, and Mr. Hidekazu Kato, a research associate at Chiba University, provided valuable research advice and we wish to express our gratitude to them.

\section{Declarations}

Conflict of interest The authors declare that they have no conflict of interest. 
Open Access This article is licensed under a Creative Commons Attribution 4.0 International License, which permits use, sharing, adaptation, distribution and reproduction in any medium or format, as long as you give appropriate credit to the original author(s) and the source, provide a link to the Creative Commons licence, and indicate if changes were made. The images or other third party material in this article are included in the article's Creative Commons licence, unless indicated otherwise in a credit line to the material. If material is not included in the article's Creative Commons licence and your intended use is not permitted by statutory regulation or exceeds the permitted use, you will need to obtain permission directly from the copyright holder. To view a copy of this licence, visit http://creativecommons.org/licenses/by/4.0/.

\section{References}

1. Environmental Protection Agency (2019) What is the Toxics Release Inventory? Toxics Release Inventory Program. https:// www.epa.gov/toxics-release-inventory-tri-program/what-toxics-release-inventory\#What\%20is \%20the\%20Toxics\%20 Release\%20Inventory? Accessed 10 Jan 2021

2. O'Neill JD, Telmer KH (2017) estimating mercury use and documenting practices in artisanal and small-scale gold mining (ASGM). United Nations Environment Programme. https:// wedocs.unep.org/bitstream/handle/20.500.11822/22894/estim ating_mercury_use.pdf. Accessed 10 Jan 2021

3. Persaud A, Telmer KH (2015) Developing baseline estimates of mercury use in artisanal and small-scale gold mining communities: a practical guide (Version 1.0). Artisanal Gold Council. http://www.briloon.org/uploads/BRI_Documents/Tropical_ Program/ASGM/AGC\%20Inventory\%20Guide_v1_Oct2015. pdf. Accessed 10 January 2021

4. Hinton JJ, Veiga MM, Veiga ACT (2003) Clean artisanal mining: a utopian approach? J Clean Prod. https://doi.org/10.1016/ S0959-6526(02)00031-8

5. Cordy P, Veiga MM, Salih I, Al-Saadi S, Console S, Garcia O, Mesa LA, Velásquez-López PC, Roeser M (2011) Mercury contamination from artisanal gold mining in Antioquia, Colombia: the world's highest per capita mercury pollution. Sci Total Environ. https://doi.org/10.1016/j.scitotenv.2011.09.006

6. Ban Toxics! (2011) The price of gold: mercury use and current issues surrounding artisanal and small-scale gold mining in the Philippines. http://www.takagifund.org/admin/img/sup/rpt_file2 0152.pdf. Accessed 10 Jan 2021

7. Veiga MM, Angeloci G, Hitch M, Velasquez-López PC (2014) Processing centers in artisanal gold mining. J Clean Prod. https://doi.org/10.1016/j.jclepro.2013.08.015

8. Esdaile LJ, Chalker JM (2018) The mercury problem in artisanal and small-scale gold mining. Chem Eur. https://doi.org/10.1002/ chem. 201704840

9. Moody KH, Hasan KM, Aljic S, Blakeman VM, Perry Hicksa L, Loving DC, Moore ME, Spencer Hammett B, Silva-González M, Seney CS, Kiefer AM (2020) Mercury emissions from Peruvian gold shops: potential ramifications for Minamata compliance in artisanal and small-scale gold mining communities. Environ Res 10:10. https://doi.org/10.1016/j.envres.2019. 109042

10. United Nations Environment Programme (2018) Global mercury assessment 2018. UNEP. https://wedocs.unep.org/bitstream/handle/20.500.11822/27579/GMA2018.pdf. Accessed 10 Jan 2021

11. United Nations Environment Programme (2020) Artisanal and small-scale gold mining. Global mercury partnership. UNEP. https://web.unep.org/globalmercurypartnership/our-work/artis anal-and-small-scale-gold-mining-asgm. Accessed 10 Jan 2021
12. Delve (2021) A global platform for artisanal \& small scale mining data. https://delvedatabase.org/data. Accessed 28 May 2021

13. Seccatore J, Veiga MM, Origliasso C, Marin T, Tomi G (2014) An estimation of the artisanal small-scale production of gold in the world. Sci Total Environ. https://doi.org/10.1016/j.scito tenv.2014.05.003

14. Tanaka Kikinzoku Kogyo KK (2020) Price information. https:// gold.tanaka.co.jp/commodity/souba/y-gold.php. Accessed 10 Jan 2021

15. Hilson G (2008) 'Fair trade gold': antecedents, prospects and challenges. Geoforum. https://doi.org/10.1016/j.geoforum.2007. 09.003

16. Veiga MM, Marshall BG (2019) The Colombian Artisanal Mining sector: where formalization is a heavy burden. Extract Ind Soc. https://doi.org/10.1016/j.exis.2018.11.001

17. United Nations Environment Programme (2020) Minamata convention on mercury. UNEP. http://www.mercuryconvention. org/Convention/Text/tabid/3426/language/en-US/Default.aspx. Accessed 10 Jan 2021

18. Fritz MMC, Maxson PA, Baumgartner RJ (2016) The mercury supply chain, stakeholders and their responsibilities in the quest for mercury-free gold. Resour Policy. https://doi.org/10.1016/j. resourpol.2016.07.007

19. Gonzalez DJX (2018) Treaty does not stop illicit mercury trade in South America, YaleGlobal. https://yaleglobal.yale.edu/conte nt/treaty-does-not-stop-illicit-mercury-trade-south-america. Accessed 10 Jan 2021

20. Korinek J (2015) Managing the minerals sector: implications for trade from Peru and Colombia. OECD Trade Policy Papers. https://doi.org/10.1787/5jrp6wrc2r71-en

21. UN Comtrade Database (2020) Exports and imports of metallic mercury. HS 280540. UN Comtrade. https://comtrade.un.org/. Accessed 10 Jan 2021

22. Echave JD (2016) La Minería Ilegal en Perú: Entre la informalidad y el delito. Nueva Sociedad 263:131-144

23. Toledo Z, Veiga MM (2018) Locals' attitudes toward artisanal and large-scale mining: a case study of Tambogrande, Peru. Extract Ind Soc 5:327. https://doi.org/10.1016/j.exis.2018.01.002

24. Veiga MM (1997) Introducing new technologies for abatement of global mercury pollution in Latin America. UNIDO/UBC/ CETEM. Rio de Janeiro. https://www.ais.unwater.org/ais/aiscm/ getprojectdoc.php?docid=409. Accessed 10 January 2021

25. Arctic Monitoring \& Assessment Programme, UN Environment Programme (2019) Technical Background Report for the Global Mercury Assessment 2018 technical report electronic annex. UNEP/AMAP. https://www.amap.no/documents/download/3411/ inline. Accessed 10 Jan 2021

26. Wood Mackenzie Ltd. (2019) Gold research suite. Wood Mackenzie Ltd. https://www.woodmac.com/research/products/metalsand-mining/gold-research-suite/. Accessed 10 Jan 2021

27. Refinitiv Metals Research (2020) Gold production 2019. Refinitiv. http://solutions.refinitiv.com/MetalsResearch. Accessed $10 \mathrm{Jan}$ 2021

28. United States Geological Survey (2020) USGS. https://prd-wret. s3-us-west-2.amazonaws.com/assets/palladium/production/atoms/ files/myb1-2017-gold-adv.xlsx. Accessed 10 Jan 2021

29. Bansah K, Yalley AB, Dumakor-Dupey N (2016) The hazardous nature of small scale underground mining in Ghana. J Sustain Mining. https://doi.org/10.1016/j.jsm.2016.04.004

30. Crawford G, Agyeyomah C, Botchwey G, Mba A (2016) The impact of Chinese involvement in small-scale gold mining in Ghana. IGC. https://www.theigc.org/wp-content/uploads/2016/08/ Crawford-et-al-2015-Final-Report-1.pdf. Accessed 10 Jan 2021

31. Lassen C, Maag J, Jønsson JB, Sarunday C (2016) Mercury trade and use for artisanal and small-scale gold mining in Sub-Saharan Africa. http://cegemi.com/wp-content/uploads/2016/02/Mercu 
ry-Sub-Saharan-Africa-Trade-Report-12-December.pdf. Accessed 10 Jan 2021

32. Ndamba R, Mlambo L, Musvovi G (2017) The contribution of artisanal and small-scale gold mining to Zimbabwe's economic growth and development. PACT. http://www.instforsustainafrica. org/wp-content/uploads/2018/10/asm-zim-report.pdf. Accessed 10 Jan 2021

33. Veiga MM, Angeloci-Santos G, Meech JA (2014) Review of barriers to reduce mercury use in artisanal gold mining. Extract Ind Soc. https://doi.org/10.1016/j.exis.2014.03.004

34. Laporte B, Quatrebarbes CD, Bouterige Y (2017) Mining taxation in Africa: the gold mining industry in 14 countries from 1980 to 2015. FERDi. https://doi.org/10.13140/RG.2.2.18562.99529

35. Hunter M (2018) Curbing illicit mercury and gold flows in West Africa: options for a regional approach. UNIDO. https://globalinit iative.net/wp-content/uploads/2018/11/Final-UNIDO-ECOWASgold-and-mercury-report-English.pdf. Accessed 10 Jan 2021

36. BBC (2020) Gold mining: how PAGMI, Nigeria Presidential Artisanal gold mining development initiative go work and benefit you. BBC. https://www.bbc.com/pidgin/tori-53436915. Accessed 10 Jan 2021

37. Spiegel SJ, Savornin O, Shoko D, Veiga MM (2006) Mercury reduction in Munhena, Mozambique: homemade solutions and the social context for change. Int J Occup Environ Health. https:// doi.org/10.1179/oeh.2006.12.3.215

38. Shandro JA, Veiga MM, Chouinard R (2009) Reducing mercury pollution from artisanal gold mining in Munhena, Mozambique. J Clean Prod 10:2. https://doi.org/10.1016/j.jclepro.2008.09.005

39. Metcalf S, Veiga MM (2012) Using street theatre to increase awareness of and reduce mercury pollution in the artisanal gold mining sector: a case from Zimbabwe. J Clean Prod. https://doi. org/10.1016/j.jclepro.2012.07.004

40. Akam S (2011) Sierra Leone's "cheap gold" entices the gullible. Reuters. https://www.reuters.com/article/uk-sierraleone-fraud/ sierra-leones-cheap-gold-entices-the-gullible-idUKTRE7112F920 110202. Accessed 10 Jan 2021

41. Chipangura $N$ (2019) Towards the decriminalisation of artisanal gold mining in Eastern Zimbabwe. Extract Ind Soc. https://doi. org/10.1016/j.exis.2018.09.003

42. Martin A, Balzac HH (2017) The West African El Dorado: mapping the illicit trade of gold in Côte d'Ivoire, Mali and Burkina Faso. Africa Portal. https://media.africaportal.org/documents/ PAC_El_Dorado_Jan_2016_EN.pdf. Accessed 10 Jan 2021

43. Telmer KH, Veiga MM (2009) World emissions of mercury from artisanal and small scale gold mining and the knowledge gaps about them. planetGOLD. https://www.planetgold.org/sites/defau lt/files/2020-05/Telmer\%20Veiga\%20World $\% 20 \mathrm{Hg} \% 20$ emmissio ns\%20from\%20ASM\%202008.pdf. Accessed 10 Jan 2021

44. Reuters (2015) Mali's gold exports down 21 pct in 2014 on drop in artisanal mining. Reuters. http://www.reuters.com/article/maligold-exports-idUSL5N0X53FU20150408. Accessed 10 Jan 2021

45. Stapper D (2018) Briefing note ASGM on the African Continent. PACT. http://www.mercuryconvention.org/Portals/11/docum ents/meetings/COP3/KL/Pact_briefing_note.pdf. Accessed 10 Jan 2021

46. Rajaee M, Obiri S, Green A, Long R, Cobbina SJ, Nartey V, Buck D, Antwi E, Basu N (2015) Integrated assessment of artisanal and small-scale gold mining in Ghana-Part 2: natural sciences review. Int J Environ Res Public Health. https://doi.org/10.3390/ ijerph120808971

47. Wilson ML, Renne E, Roncoli C, Agyei-Baffour P, Tenkorang EY (2015) Integrated assessment of artisanal and small-scale gold mining in Ghana - Part 3: social sciences and economics. Int J Environ Res Public Health. https://doi.org/10.3390/ijerph1207 08133
48. Armah FA, Luginaah IN, Taabazuing J, Odoi JO (2013) Artisanal gold mining and surface water pollution in Ghana: have the foreign invaders come to stay? Environ Justice. https://doi.org/10. 1089/env.2013.0006

49. Hilson G, McQuilken J (2014) Four decades of support for artisanal and small-scale mining in sub-Saharan Africa: a critical review. Extr Ind Soc. https://doi.org/10.1016/j.exis.2014.01.002

50. Artisanal Gold Council (2019) Estimations initiales nationales du Secteur de l'Extraction Artisanale et à Petite Échelle d'Or au Sénégal Conformément à la Convention de Minamata sur le Mercure. AGC. https://www.artisanalgold.org/wordpress/wp-content/ uploads/2019/11/Senegal-Inventory-Report.pdf. Accessed 10 Jan 2021

51. Alvarez YB, Coué B, Schein P (2016) Analysis report supply chains of artisanal gold in West Africa. UNIDO. https://www. responsiblemines.org/wp-content/uploads/2018/04/Publicationsupply-chains-artisanal-gold-west-africa_-ENGL_-baja.pdf. Accessed 10 Jan 2021

52. Blore S (2015) Contraband gold in the great lakes region inregion cross-border gold flows versus out-region smuggling. BGR. https://impacttransform.org/wp-content/uploads/2017/ 09/2015-May-Contraband-Gold-in-the-Great-Lakes-Region-InRegion-Cross-Border-Gold-Flows-Versus-Out-Region-Smugg ling.pdf. Accessed 10 Jan 2021

53. Rodriguez J (2010) Gold fever: artisanal and industrial extraction in the Nicaraguan Mining Triangle. Upside Down World. http://upsidedownworld.org/archives/nicaragua/gold-fever-artis anal-and-industrial-extraction-in-the-nicaraguan-mining-trian gle/. Accessed 10 Jan 2021

54. Garcia O, Veiga MM, Cordy P, Suescún OE, Molina JM, Roeser M (2015) Artisanal gold mining in Antioquia, Colombia: a successful case of mercury reduction. J Clean Prod. https://doi.org/ 10.1016/j.jclepro.2014.11.032

55. Veiga MM, Thomas J (2013) Evaluation of the mercury use in artisanal and small-scale gold mining in Nicaragua. In: Proceedings of the 11th international conference of mercury as a global pollutant. Edinburgh, Jul 27-Aug 2, 2013 (abstract)

56. Veiga MM, Baker R (2004) Protocols for Environmental and Health Assessment of Mercury Released by Artisanal and Small-scale Gold Miners. Global Mercury Project. https:// iwlearn.net/resolveuid/617e8a7184a7ec1e292a61c2319dc30f. Accessed 10 Jan 2021

57. Harlow DE, Hurley K, Fox A, Vargas-Guerra A, Gibson J (2019) Small-scale \& artisanal mining impacts on biodiversity in Latin America. USAID. https://www.land-links.org/wp-conte nt/uploads/2019/10/ASM_White-Paper_USAID_FINAL_21Mar ch2019Final.pdf. Accessed 10 Jan 2021

58. Lundin Mining (2016) Sustainability report. Lundin Mining. https://www.lundinmining.com/site/assets/files/3622/lmc_csr20 16_final_web_rev_lr_spreads.pdf. Accessed 10 Jan 2021

59. Ministerio de minería y metalurgia (2019) Situación de la minería y boletín estadístico tercer trimestre 2019. http://www.miner ia.gob.bo/revista/pdf/boletin3t2019.pdf. Accessed 10 Jan 2021

60. Cremers L, Kolen J, Theije MEM (2013) Small-scale gold mining in the Amazon. The cases of Bolivia, Brazil, Colombia, Peru and Suriname. CEDRA. Amsterdam

61. Marshall BG, Camacho A, Jimenez G, Veiga MM (2021) The mercury reality challenges in Mexico: regulatory and environmental impacts. Atmosphere. https://doi.org/10.3390/atmos 12010057

62. Sousa RN, Veiga MM (2009) Using performance indicators to evaluate an environmental education program in artisanal gold mining communities in the Brazilian Amazon. J Human Environ. https://doi.org/10.1579/0044-7447-38.1.40

63. Sousa RN, Veiga MM, Van Zyl D, Telmer KH, Spiegel S, Selder J (2011) Policies and regulations for Brazil's artisanal gold mining 
sector: analysis and recommendations. J Clean Prod. https://doi. org/10.1016/j.jclepro.2010.12.001

64. Fantastico (2020) Tonnes of mercury enter Brazil clandestinely to supply artisanal gold mining (in Portuguese). Fantastico. https:// g1.globo.com/fantastico/noticia/2020/08/30/toneladas-de-mercu rio-entram-clandestinamente-no-pais-para-abastecer-garimpo-deouro.ghtml. Accessed 10 Jan 2021

65. Gonçalves AO, Marshall BG, Kaplan RJ, Chavez JM, Veiga MM (2017) Evidence of reduced mercury loss and increased use of cyanidation at gold processing centers in southern Ecuador. J Clean Prod. https://doi.org/10.1016/j.jclepro.2017.07.097

66. Minam PM, Egg AB, Álvarez J, Sotero V, Peralta CI (2011) Minería aurífera en Madre de Dios y contaminación con mercurio: Una bomba de Tiempo. SINIA. https://sinia.minam.gob.pe/docum entos/mineria-aurifera-madre-dios-contaminacion-mercurio-unabomba-tiempo. Accessed 10 Jan 2021

67. Sutherland IG (2019) The political ecology of mercury within the small-scale gold sector Guyana Report. IUCN. https://www.iucn. nl/files/groene_economie/regional_mercury_report_guyana.pdf. Accessed 10 Jan 2021

68. Veiga MM, Marshall BG (2016) Why does Canada export mercury to Cuba? Extract Ind Soc. https://doi.org/10.1016/j.exis. 2016.01.004

69. Veiga MM (1997) Artisanal Gold Mining Activities in Suriname. UNIDO. http://artisanalmining.org/Repository/02/The_GMP_ Files/raw\%20files\%20-\%20globalmercuryproject.org/LatAm erica/Suriname/UNIDO\%20Veiga\%20Suriname1997-nomap. pdf. Accessed 10 Jan 2021

70. Legg ED, Ouboter PE, Wright MAP (2015) Small-scale gold mining related mercury contamination in the Guianas: a review. WWF Guianas. http://d2ouvy59p0dg6k.cloudfront.net/downloads/mercu ry_contamination_in_the_guianas_2015.pdf. Accessed 10 Jan 2021

71. Seccatore J, Theije M (2017) Socio-technical study of small-scale gold mining in Suriname. J Clean Prod. https://doi.org/10.1016/j. jclepro.2016.12.119

72. Ramsés US (2019) Behind the gold mining company that props up Maduro's regime. Caracas chronicles. https://www.caracaschr onicles.com/2019/03/23/behind-the-gold-mining-company-thatprops-up-maduros-regime/

73. Wagner L (2016) Organized crime and illegally mined gold in Latin America. Global Initiative. https://globalinitiative.net/analy sis/organized-crime-and-illegally-mined-gold-in-latin-america/. Accessed 10 Jan 2021

74. Balifokus (2015) IPEN Mercury Treaty Enabling Project, Indonesia. IPEN. https://16edd8c0-c66a-4b78-9ac3-e25b63f72d0f.files usr.com/ugd/13eb5b_e95e7961efb04b6e9248f446629036f2.pdf. Accessed 10 Jan 2021

75. Balifokus (2017) Mercury trade and supply in Indonesia. IPEN. https://16edd8c0-c66a-4b78-9ac3-e25b63f72d0f.filesusr.com/ ugd/13eb5b_bf0b2658eccf40cc9dbbb3a6514e9d64.pdf. Accessed 10 Jan 2021

76. Drwiega YI (2018) Illegal and illicit mercury trade in Indonesia. https://16edd8c0-c66a-4b78-9ac3-e25b63f72d0f.filesusr.com/ ugd/13eb5b_f0dd64cbceda413e8c3dbb3943e1975f.pdf. Accessed 10 Jan 2021

77. Spiegel SJ, Agrawal S, Mikha D, Vitamerry K, Le Billon P, Veiga MM, Konolius K, Paul B (2018) Phasing out mercury? Ecological economics and Indonesia's small-scale gold mining sector. Ecol Econ. https://doi.org/10.1016/j.ecolecon.2017.07.025

78. Castilhos ZC, Rodrigues-Filho S, Rodrigues AP, Villas-Bôas RC, Siegel S, Veiga MM, Beinhoff C (2006) Mercury contamination in fish from gold mining areas in Indonesia and human health risk assessment. Sci Total Environ. https://doi.org/10.1016/j.scitotenv. 2006.01.039
79. Rasmus KR, Maria W, Marie B, Richard G, Erik J, Jane T (2016) Mercury pollution from small-scale gold mining can be stopped by implementing the gravity-borax method-a two-year follow-up study from two mining communities in the Philippines. Environ Occup Health Policy. https://doi.org/10.1177/1048291115607929

80. Catedral S, Manza M, Ocate A (2020) Philippines: the artisanal mining sector during the COVID-19 pandemic. Artisanal Gold Council. https://www.artisanalgold.org/2020/04/philippines-prote cting-the-artisanal-mining-sector-during-the-covid-19-pandemic/. Accessed 10 Jan 2021

81. Francisco R (2012) Special report: Philippines' black market is China's golden connection, Reuters. https://www.reuters.com/artic le/us-philippines-gold/special-report-philippines-black-market-ischinas-golden-connection-idUSBRE87M02120120823. Accessed 10 Jan 2021

82. Evans S (2019) The future of small-scale gold mining in the Philippines. Mining Technology. https://www.mining-technology. com/features/the-future-of-small-scale-gold-mining-in-the-phili ppines/. Accessed 10 Jan 2021

83. Singo P, Seguin K (2018) Best practices: formalization and due diligence in artisanal and small-scale mining. Impact. Africa Portal. https://media.africaportal.org/documents/IMPACT_ASMBest-Practices_May-2018-EN-web.pdf. Accessed 10 Jan 2021

84. Deb M, Tiwari G, Lahiri-Dutt K (2008) Artisanal and small scale mining in India: selected studies and an overview of the issues. Int J Mining Reclam Environ. https://doi.org/10.1080/1748093070 1679574

85. Deb M (2016) Artisanal and small-scale gold mining and related mercury usage in India. 35th International Geological Congress Abstracts. American Geosciences Institute. https://www.ameri cangeosciences.org/sites/default/files/igc/805.pdf. Accessed 10 Jan 2021

86. Deb M, Sarkar SC (2017) Mines and minerals sector in india and its regulatory regime. In: Minerals and allied natural resources and their sustainable development. Springer Geology. Springer, Singapore. https://doi.org/10.1007/978-981-10-4564-6_10

87. NS Energy (2020) Production resumes at Sepon gold mine in Laos after six years. NS Energy. https://www.nsenergybusiness.com/ news/production-sepon-gold-mine-laos/. Accessed 10 Jan 2021

88. Houngaloune S, Inthavongsa I (2019) Trends of gold mining industry in Lao PDR. 13th international conference on mining, materials and petroleum engineering. CMMP2019. https://www. researchgate.net/publication/334635927_Trends_of_gold_mining_industry_in_Lao_PDR. Accessed 10 Jan 2021

89. Moretti D, Garrett N (2018) Artisanal and small-scale mining governance: The 'emerging issue' of 'unregulated mining' in Lao PDR. In: Lahiri-Dutt K (ed) Between the plough and the pick: Informal, artisanal and small-scale mining in the contemporary world. ANU Press, Canberra, pp 311-334

90. Baker R, Wotruba H, Aucoin E, Figueiredo K, Bougnaphalom E (2007) Lao PDR summary report. United Nations Industrial Development Organization, Global Mercury Project. http://archi ve.iwlearn.net/globalmercuryproject.org/countries/laos/docs/ Laos\%20Final\%20Report.pdf. Accessed 10 Jan 2021

91. Gunson AJ, Veiga MM (2004) Mercury and artisanal gold mines in China. Environ Practice. https://doi.org/10.1017/S146604660 4000225

92. U.S. Government Publishing Office (2019) Illicit mining: threats to U.S. national security and international human rights. https:// www. foreign. senate.gov/download/transcript-120519-01. Accessed 10 Jan 2021

93. InSight Crime (2021) Dirty business - the smuggling pipeline carrying mercury across the Amazon. https://insightcrime.org/news/ dirty-business-smuggling-pipeline-carrying-mercury-amazon/. Accessed 28 May 2021 
94. Springer SK, Peregovich BG, Schmidt M (2020) Capability of social life cycle assessment for analyzing the artisanal smallscale gold mining sector-case study in the Amazonian rainforest in Brazil. Int J Life Cycle Assess. https://doi.org/10.1007/ s11367-020-01828-3

95. Hunter M (2019) Pulling at golden webs: Combating criminal consortia in the African artisanal and small-scale gold mining and trade sector. ENACT. https://enact-africa.s3.amazonaws.com/site/ uploads/2019-04-24-pulling-the-golden-webs-research-paper.pdf. Accessed 10 January 2021
96. Marshall BG, Veiga MM, Silva HAM, Guimarães JRD (2020) Cyanide contamination of the Puyango-Tumbes river caused by Artisanal gold mining in Portovelo-Zaruma Ecuador. Curr Environ Health Rep 10:20. https://doi.org/10.1007/s40572-020-00276-3

Publisher's Note Springer Nature remains neutral with regard to jurisdictional claims in published maps and institutional affiliations. 